Journal of American Studies, 49 (201 5), 4, 793-8 I I

(C) Cambridge University Press and British Association for American Studies 2015. This is an Open Access article, distributed under the terms of the Creative Commons Attribution licence (http://creativecommons.org/licenses/by/4.0/), which permits unrestricted re-use, distribution, and reproduction in any medium, provided the original work is properly cited.

doi:10.1017/S0021875815001723 First published online 12 October 2015

\title{
The Walking Dead: Late Liberalism and Masculine Subjection in Apocalypse Fictions
}

\author{
KATHERINE SUGG
}

From The Road to The Walking Dead, contemporary apocalyptic fictions narrativize the conjunction of two central "crises": late liberal capitalism and twenty-first-century masculinity. This conjunction underlines the insights of a variety of scholars and cultural critics who analyze the "crisis" of contemporary masculinity, often specifically white masculinity, as a product of recent economic and social transformations, including the perceived disempowering of white male authority in a neoliberal era of affective labor, joblessness and multiculturalism. But the apocalypse, especially as a television series, is a rather peculiar narrative vehicle for the articulation of a transformative future for - or a nostalgic return to - masculine agency and authority. Focussing on questions of subjection and agency in the late liberal/neoliberal moment, I suggest that zombie apocalypse stages a debate on the status of masculine agency that has roots extending deep into the foundations of liberal modernity and the gendered selfhood it produces - roots that are ironically exposed by the popular cultural referent that dominates The Walking Dead: the frontier myth. The frontier and the apocalypse both draw from Hobbesian prognostications of a state of nature as relentless competition and a war of "all against all" that are foundational to modern liberal political theory and questions of sovereignty, self-interest, and collective governance. But they also index a narrative antidote to the erasure of political agency as traditionally enshrined in liberal democratic norms and traditions. Like the western, the zombie apocalypse speculates about possible ways in which masculine agency in liberal modernity might be reimagined and/or reinvigorated. In the place of a tired, automated neo-"official man", the apocalypse in The Walking Dead promises an opportunity to "finally start living" - reminding us that white masculinity figures precisely the Enlightenment liberal subject-citizen and the authoritative, if highly fictional, agency which has been notoriously crushed within regimes of late capitalist biopower. And yet, even as the zombie apocalypse engages foundational myths of liberal modernity, it elaborates them in surprisingly nihilistic set pieces and an apparently doomed, serial narrative loop (there is no end to the zombie apocalypse and life in it is remarkably unpleasant). The eruption of haptic elements in the television show - especially in the visual and aural technologies that allow representations of bodies, suffering, dismemberment, mutability, disgust - further counters the apparent trajectory of apocalyptic allegory and opens it to alternative logics and directions. The narrative options of the zombie apocalypse thus seem to be moving "back" to a brutal settler colonial logic or "forward" to an alternative, perhaps more ethical, "zombie logic," but without humans. This essay is interested in what these two trajectories have to say to each other and what that dialogue, and dialectic, indicate about contemporary economic

English Department, Central Connecticut State University. Email: suggkae@ccsu.edu. 
governance as it is experienced and translated affectively into popular narrative and cultural product. That is, to what extent is the racist and economic logic of settler colonialism already infected by the specter of another logic of abjection and otherness, one that is figured both by the zombies and by the nonnarrative function of spectacles of embodied male suffering? And what does that slippage between logics and directions tell us about the internal workings of settler colonialism and economic liberalism that have always been lodged within mythic fantasies of the frontier?

A post-apocalyptic genre can't exist without the possibility of hope.

Colson Whitehead ${ }^{\mathrm{I}}$

\section{MASCULINITY AND NEOLIBERAL CRISIS: GENERIC GENEALOGIES FOR THE WALKING DEAD}

In the episode "I 8 Miles Out" during Season 2 of the blockbuster television series The Walking Dead, we find the main character and ostensible hero of the series, a haggard Rick Grimes (played by Andrew Lincoln), agonizing that his best friend Shane thinks he is "too soft" and that because he wants to be "the good guy," Rick won't be able to do what is necessary to keep their group alive amid the horrors of the zombie apocalypse. By this point, viewers of the show are familiar with Rick and his group's plight, their struggle to find ways to survive while also avoiding being bitten and infected by the "walking dead." About five months before this episode, in narrative time, the "walkers" appeared in all their ambling glory and caused a total breakdown of society, including the apparent destruction of any government or technology infrastructure. Apart from Shane, Rick's group includes his ten-year-old son Carl and wife Lori. Through flashbacks, viewers learn that before the zombie apocalypse, in addition to being close friends, Rick and Shane (Jon Bernthal) were partners as deputy sheriffs in a small town in rural Georgia. Ostensibly, his "natural" authority and previous career as a cop explain why so many characters, including Lori in this episode, insist, "We need Rick." The narrative begins with Rick waking from a coma and locating, rather miraculously, his wife and son, and Shane, who have joined a small group of survivors in the very early days of the zombie event. From the first episodes, Rick's fitness to lead this group is both a foregone conclusion and an ongoing question.

That persistent question of who should lead suggests particular assumptions about the requirements of collective survival, as well as a preoccupation with problems of governance. Though familiar from a long history of disaster and end-of-the world movies, these assumptions depend on conventional

I Nick Romeo. "Colson Whitehead: I had Zombie Anxiety Dreams for Years," Salon.com, May 3 I 20I4, at http://TheWalkingDead.salon.com/2014/05/3I/colson_whitehead_i_ had_zombie_anxiety_dreams_for_years/?source=newsletter. 


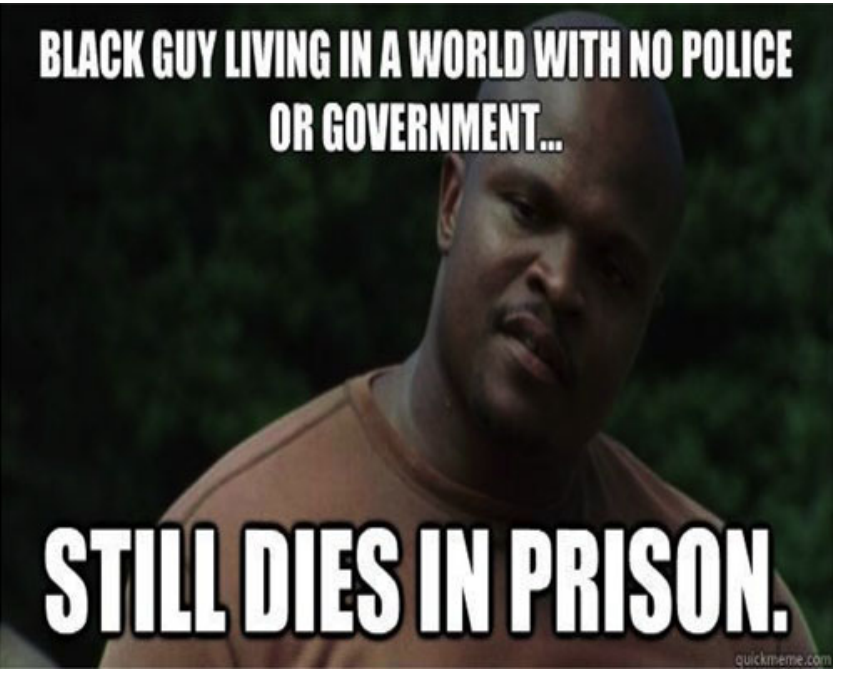

Figure I. Theodore "T Dog” Douglas (Iron ESingleton), "Still Dies in Prison” meme, 20 I 2.

and deeply embedded notions about what enables a "society" to function, what makes a "strong" leader, and why that leader is needed. The focus on Rick also reflects The Walking Dead's regressive conception of gender: Lori (Sarah Wayne Callies) expresses her nurturing and protective nature while Rick is shown to be level-headed, quick-acting, and good at perceiving and planning for dangers. How the group naturally turns to Rick for guidance and decision-making is the main focus of the first episodes. The show's stereotyping extends to its racial coding as well: in the first three seasons, non-white characters largely play supporting, and usually disposable, roles. A plethora of memes (Figures I and 2) using images from The Walking Dead mockingly observe that "Whether the Civil War or a zombie apocalypse, Mammy gonna take care of Miss Scarlett," and "Black guy living in a world with no police or government ... Still dies in prison."

This reactionary element in The Walking Dead indicates how - in a move familiar from other post-apocalypse movies, tv shows, and video games - the plot provides a narrative return to what are described as "basic" conditions of survival as indicated by social life, technological resources, and skills needed. These are conditions that not coincidentally seem to require a parallel return to social norms of gender and racial difference that are foundational to the dominance of white men in collective life. Such norms are grounded in classical liberal conceptions of individual agency and responsibility as well as the histories of conquest, settlement, and dominance known as "settler colonialism." Or, put another way, the show's survival plot and its nostalgic return to premodern conditions offer settings and plot elements that are 


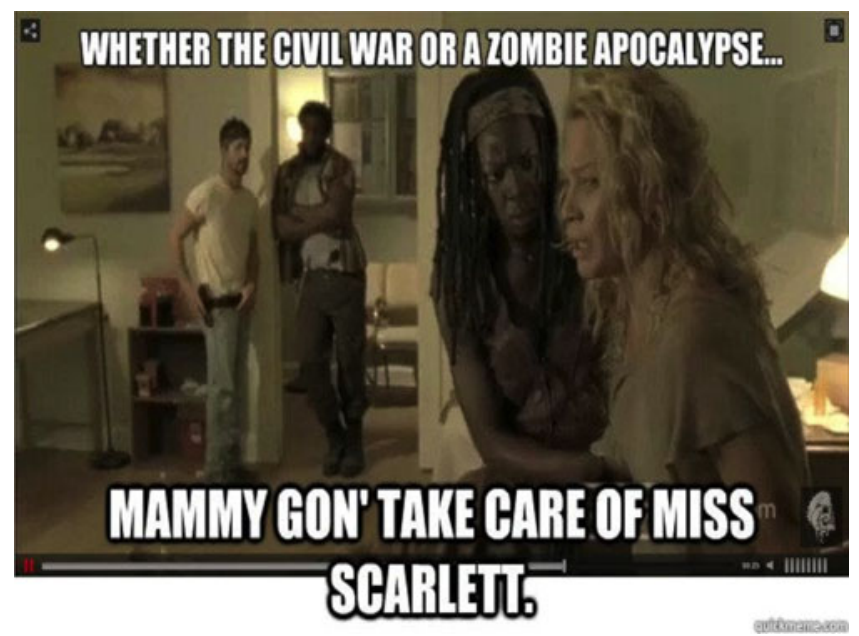

Figure 2. Michonne (Danai Gurira) and Andrea (Laurie Holden) in "Mammy" meme, 20 I 2.

central to both the zombie apocalypse of The Walking Dead and one of its key generic forebears, the Hollywood western. Emphasizing that generic resonance underlines The Walking Dead's preoccupation with nostalgic regressions but also raises the question of what this connection between zombie horror and frontier myth might tell us about a genealogy of "public feelings" and their relations to economic and social conditions as captured in popular culture.

In contrast to the backward-looking settings and plots of classic westerns, The Walking Dead takes place in a contemporary near-future that clearly mirrors the actual present, albeit with the radical transformation of the social and material landscape caused by the zombie virus. Two aspects of this mimetic presentation of a contemporary setting and its implied links to a settler colonial past are particularly relevant to the dramas of masculine leadership and collective crisis that unfold: one is the legacy of liberal and neoliberal economic structuring of social formations and subjective experience (often known as biopolitics and/or governmentality, following Foucault) and the other is the function of white masculinity in that liberal legacy. Anna McCarthy defines neoliberalism as an economic and political regime "in which state policies synchronize with cultural practices to apply marketbased individualism as a governmental rationale across the institutions and practices of everyday life." ${ }^{2}$ Likewise, Eva Cherniavksy emphasizes the

2 Anna McCarthy, "Reality Television: A Neoliberal Theatre of Suffering," Social Text 93 , 25, 4 (Winter 2007), 17-4I, 20-2I, explains governmentality as a key concept in Foucault's understanding of "the technique of dispersed government," which "provides a 
impact of neoliberalism on understandings of the responsibilities of citizens and the state, in which the neoliberal state "abdicates" its collective function in favor of the expanding imperative to "secure private property." 3 Both definitions indicate the rise of what sociologist Nikolas Rose calls "responsibilization," marking the neoliberal shift of both public life and subjective states to individual control and responsibility. ${ }^{4}$ That is, the conditions depicted in The Walking Dead's survivalist narrative and the questions its plot raises about leadership and collectivity can be understood as a fantasy template for social and individual action after neoliberalism's destruction of the welfare state - presented here as the work of the zombie virus. Although the western's "frontier" conditions (in which the mettle of individual men is tested by the crucible of wilderness environments and hostile "savages") pre-date this neoliberal abandonment of the public sphere, the resonance between the two scenarios indicates how discourses of individual agency and responsibility in both eras emerge from a shared understanding of moral and political values, a conception of the "good" that not coincidentally supports the interests of capital.

But while emphasizing the success (and superiority) of entrepreneurial, selfmanaging individuals, the present moment is also one in which the traditional dominance of men is increasingly in question - or crisis, depending on the political leanings of the commentator. The historical confluence of feminist and multicultural challenges to white male supremacy and neoliberal transformations of everyday practices of governance, labor, identity, and citizenship have undermined the privileges and economic assumptions associated with normative white masculinity. As implied in media terms such as "mancession" and "he-cession," the economic decline of 2008 has been widely characterized by its particular hardship for men, who held more than 80 percent of the jobs lost in the US between 2008 and 2010.5 What others have called the "proletarianization" of the US middle class, and of society as a whole, describing wide-scale demotion of relatively autonomous professionals to underpaid and over-supervised wage labor, points to a general experience of impotence, the logics of which may be economic but which is experienced as affective malaise and psychic pain. ${ }^{6}$ Such humiliations and losses confirm the sense

powerful model for understanding the cultural and political manifestations of neoliberalism."

3 Eva Cherniavsky, "Neocitizenship and Critique," Social Text 99, 27, 2 (Summer 2009), I-23, 4.

${ }^{4}$ Nikolas Rose, Powers of Freedom: Reframing Political Thought (Cambridge: Cambridge University Press, 1999).

5 Michael Kimmel, Angry White Men: American Masculinity at the End of an Era (New York: Nation Books, 2013).

${ }^{6}$ Jodi Dean cites Žižek's call for an expansion of Marx's definition of proletarianization to include modes of existence and subjectivity beyond the purely economic and labor sectors to 
that, subject to increasingly powerful apparatus of control, individuals and identities do not "matter" like they used to. Or at least that is a conclusion shared by both right-wing media commentators and leftist political and cultural theorists of late capitalism, together echoing a long-standing fear in US popular culture that Timothy Melley encapsulates in the term "agency panic."

Tracing popular expressions of anxiety about liberal subjectivity and individual sovereignty (i.e. the "self-directed individual") from World War II to the present, Melley defines agency panic as "an attempt to conserve the integrity of the liberal, rational self" - often in the face of "new ideas about subjectivity," including theories from consumer research, social psychology, science fiction, cybernetics, and post-structural theory.7 The literary narratives (and sociological studies and policy discourses) that Melley analyzes mark a longstanding "crisis" of liberal individualism and indicate a key sociocultural genealogy for the narrative preoccupations of The Walking Dead and the fantasies it feeds, particularly when it presents a world transformed by the zombies into a place with "no government, no grocery stores, no mail delivery, no cable TV." 8 These challenging conditions offer a dramatic antidote to the passivity of everyday life familiar to viewers, especially men such as the subject in a recent study by masculinities researcher Michael Kimmel, who "considered himself a victim of the impersonal forces that wreak havoc with the lives and the futures of America's middle and working classes." Echoing numerous other critics and researchers, Kimmel's work emphasizes the specific impact on men and traditional notions of masculinity created by economic decline and thus participates in a public discourse that implicitly privileges male hegemony

better account for the psychic and social impacts of neoliberalism. Indicating the gendered aspect of proletarianization, Dean also refers to economists David Autor and David Dorn on employment trends over the past 30 years: decreasing numbers of jobs in mining, assembling, operating, and transporting and substantially increasing ( $53 \%$ between 1980 and 2005) jobs in child care, hairdressing, food service, home health care, cleaning, and gardening. Jodi Dean, The Communist Horizon (New York: Verso, 201 2), 106, 108.

7 Timothy Melley, Empire of Conspiracy: The Culture of Paranoia in Postwar America (Ithaca, NY: Cornell University Press, 2000), 37.

${ }^{8}$ Robert Kirkman (writer), Tony Moore, Charlie Adlard, Cliff Rathburn, and Rus Wooton, The Walking Dead: Compendium One (Berkeley, CA: Image Comics, 2010), back cover (also of each issue of the comic series).

9 Kimmel, 20r. Kimmel's assertion that men feel particularly victimized by neoliberal, or global, capitalism echoes an emphasis on the gendering of economic crisis in analyses by Melley; Susan Faludi, Stiffed: The Betrayal of the American Man (New York: Harper Perennial, 2000); Hamilton Carroll, Affrmative Reaction: New Formations of White Masculinity (Durham, NC: Duke University Press, 20I I). Carroll specifically notes how the transformation of economic conditions into gendered and racialized narratives is a recuperative move on behalf of hegemonic white masculinity. 
as a key marker of what is being "lost" and/or transformed in the neoliberal present.

The emasculation and crisis of white masculinity, as well as other forms of agency in collective life, are therefore "problems" that The Walking Dead places at the center of the drama of Rick and the group and the conditions and challenges they face. The show initially presents audiences with a general scenario in which individual agency is reinvigorated by the zombie apocalypse: or as the back cover of each issue of The Walking Dead comics series admonishes the reader,

How many hours are in a day when you don't spend half of them watching television? When is the last time any of us REALLY worked to get something we wanted? The world we knew is gone. The world of commerce and frivolous necessity has been replaced by a world of survival and responsibility ... In a matter of months society has crumbled, no government, no grocery stores, no mail delivery, no cable TV. In a world ruled by the dead, we are forced to finally start living. ${ }^{10}$

Opposing a world of "frivolous necessity" in "our" consumerist society to its replacement by a "world of survival and responsibility" specifies the promise of these "new" conditions: they can give "you" a life worth living. How this worth is ascertained relies on a gesture that pairs individual responsibility with modes of necessity that are assumed to be more rewarding, even if "forced." Choices now matter and actions have consequences. Commerce and its "frivolous" activities and a nanny state that exists to promote more consumption are coded as a kind of living death which is transformed by apocalypse into a (compulsory) opportunity to "finally start living."

This survivalist scenario confirms the axiom of neoliberal governmentality, as described by McCarthy, "that individuals are sovereign beings best ruled under circumstances in which they are encouraged to self-manage, taking on responsibilities for their welfare, growth, and security that might otherwise be assumed by the state." ${ }^{\prime \prime}$ And thus the ostensible opportunity for liberal subjects offered by The Walking Dead involves a stark ideological complicity with the dictates of neoliberalism. Both the back cover's "promise" and the show's premise seem to affirm a strong version of liberal sovereign individuality that in a sense "teaches" the benefits of responsibilization. Likewise, the development of its agential, self-reliant survivor characters further demonstrates how television genres can provide "templates" and an arena for the development of subjectivities that "complement the privatization of public life." ${ }_{12}$ And yet the

10 Kirkman et al., back cover.

${ }^{11}$ McCarthy, 25.

${ }^{12}$ Laurie Ouellette, "Take Responsibility for Yourself: Judge Judy and the Neoliberal Citizen," in Laurie Ouellette and Susan Murray, eds., Reality TV: Remaking TV Culture (New York: New York University Press, 2004), 223-42, 23 I. 
forcing of these conditions indexes a less celebratory affective response and a more critical understanding of what it means to have to "REALLY" work to get something you want (or, in the case of this show, actually need to survive).

Jane Elliott coins the term "suffering agency" to articulate the shift in subjectivity generated by the work of "self-preservation" under neoliberalism, in which the imperative of self-interest leads characters in popular narratives to take increasingly drastic, often abhorrent, action in order to survive under conditions that are imposed by distant, unseen forces: a scenario that describes both horror film franchises such as the Saw movies and survivalist memoirs including Alive and 27 Hours. By their very nature, Elliott suggests, survivalist narratives conscript characters into situations that register the real problem, and the real horror, of individual responsibility and agency under neoliberalism: "As we witness the frenzied, desperate, and at times appalling actions humans undertake to preserve themselves in survival tales, we see behavior so driven that it seems on the boundary of the voluntary and involuntary." For Elliott, the question raised by survival narratives indexes a large-scale perception that might also be usefully applied to The Walking Dead and its popularity: viewers' compelling if unpleasant fascination with the show's horrific no-win situations reflects "something of the inescapable, obligatory cast of interest under neoliberalism." ${ }^{\text {3 }}$

Wiping out large-scale markers of contemporary modernity in The Walking Dead therefore does two things: (I) it re-creates scenarios that mimic experiences of neoliberal governmentality as a series of "crises" that force subjects into self-directed, highly consequential action, and (2) it dramatizes processes of community formation and individual psychic and physical adaptation that have to take place under these conditions of survival. The tasks of forming human groups into functioning defensive communities - and living rather than the dying-compel a recourse to "premodern" ways of life and skills that include scavenging, living off the land, and defending oneself against aggressors, both the hordes of the undead and other humans. As underlined in episode titles such as "Triggerfinger," "Nebraska," and "Cherokee Rose," both of these threats - the "walkers" and violent and competing groups of living humans - are understood through a series of tropes and plotlines that invoke the frontier West and Hollywood westerns.

The clean slate of the show's post-apocalypse thus renders quite vividly, and with explicit visual and narrative cues, a frontier setting in which individuals and groups must learn to make their own rules and preserve a fledgling and

${ }^{13}$ Jane Elliott, "Suffering Agency: Imagining Neoliberal Personhood in North America and Britain," Social Text II5, 32, I (Summer 2013), 83-101, 92. 
isolated community located in a hostile landscape. Both the western and The Walking Dead present audiences with an explicitly white masculinist survival narrative whose apparent goal is to uphold the mythologies of liberal ideology and individualism. However, what also become clear are the foreboding implications of both the classical and neoliberal logics of collective and individual agency that are elaborated in The Walking Dead: there is no end to the zombie virus and life in the post-apocalypse is remarkably unpleasant. In its nihilistic set pieces and doomed, serial narrative arc, the thwarted options available to the main characters and the horrors of its "post-frontier" setting problematize The Walking Dead's seeming nostalgia. These contradictions and the ambivalences they reflect constitute a pop-culture index of responses and expectations regarding liberal capitalism and neoliberal governance that are more complex and critical than they might first appear.

For one thing, as a "crisis," the zombie apocalypse of The Walking Dead is never-ending and, to all intents and purposes, hopeless: by the end of Season I, viewers learn that "everyone" is infected and, regardless of whether they are bitten by a "walker" or not, will reanimate upon death unless their brains are smashed or shot. Furthermore, each episode emphasizes how the zombies always return to the scene to bite, maim, or dismember someone, often a main character. $^{\mathrm{I} 4}$ Indeed, up to the current moment in its dual narration (the television series began Season 5 in October 2014 and the comic book series continues to be published with Volume 22 released in November 20I4), every newly formed, functioning human collective and safe haven established by Rick and his friends is destroyed by "roamers," and/or other humans, after which the various survivors are left to scatter and figure out a way to start over. This seemingly endless cycle of painful effort followed by the destruction and loss of all that the characters have "worked for" creates a serial narrative in the shape of a static holding pattern; the seriality ensures a cyclical return that brings no change and no movement forward. This pattern literalizes what Lauren Berlant describes as the stasis and "exhaustion" of political, social, and psychic - as well as economic - expectations in neoliberalism's current "time of dithering" and "wandering." "s Coinciding with the zombie apocalypse's narrative temporality of "crisis" (of apocalypse, emergency, etc.) that registers contemporary worries about the end of capitalism, "our" way of life, and the collapse of faith in any path forward, The Walking Dead installs a temporality of "impasse" in which

${ }^{14}$ This is known as the "Anyone Can Die" trope in online fan publications: http://tvtropes. org/pmwiki/pmwiki.php/Series/TheWalkingDead. Steven Shaviro's influential work on zombie film narratives emphasizes the wish-fulfillment aspect of such scenes depicting the brutal, grotesque deaths of loved ones and neighbors. Steven Shaviro, The Cinematic Body (Minneapolis: Minnesota University Press, 1993).

is Lauren Berlant, Cruel Optimism (Durham, NC: Duke University Press, 201 I), 4. 
the impotence and stasis of late neoliberal capitalist subjectivity is built into its narrative structure.

In his influential reading of the iconic zombie films of George Romero, Steven Shaviro emphasizes that identification with the films' ostensible protagonists is often interrupted by the zombies themselves, whose "peculiar fascination" and charisma come to dominate audiences' affective responses to what happens on-screen. ${ }^{16}$ The narrative temporality of wandering and failure, the narrative stasis of The Walking Dead, can be understood as another element "that undermines our nominal involvement with the films' active protagonists" and thwarts audiences' complacent internalization of the characters as "templates" for responsibilization or self-directed agency. And yet, in The Walking Dead's updating of the zombie narrative, the character-driven plots and development of specific storylines are what critics and audiences most emphasize when accounting for the show's immense audience share. Even with the growing contradiction between its nostalgic, even regressive, characterizations and a larger narrative structure that refuses progress, resolution, or heroism, Rick and his "family," along with other key individual (mostly male) characters, are the main focus of discussion. ${ }^{17}$ These audiences persist as The Walking Dead's drama of embattled white masculinity is relentlessly twisted back on itself, particularly by Season 4, when Rick has abdicated his position as an increasingly dictatorial (and brutal) leader and attempts to live peacefully and democratically among his fellow survivors.

Still, it is Rick who continues to occupy the narrative's central position, along with the rather unpopular character of his son Carl (Chandler Riggs). Lori has been done away with - dying in childbirth, no less - toward the end of Season 3 of the television show. Considering the deaths of both Lori and her baby daughter in the comic book series, Gerry Canavan observes that this "is the moment that basically all hope is lost in The Walking Dead." ${ }^{8}$ And yet readers and television audiences have stayed with Rick

16 Shaviro, 96.

${ }_{17}$ The premiere episode of The Walking Dead broke records for AMC viewership (over 5 million), while that of Season 2 had I I million views and the Seasons 3 and 4 premiers each had more than is million. Glowing reviews across the Web include those from the entertainment site Rotten Tomatoes, which wrote, "The second season of The Walking Dead fleshes out the characters while maintaining the grueling tension and gore that made the show a hit," indicating here and elsewhere that the combination of "gore" and a "deeper sense of the people" constitutes the show's winning formula.

${ }^{18}$ Gerry Canavan, "We Are the Walking Dead': Race, Time, and Survival in Zombie Narrative, Extrapolation, 5I, 3 (2010), 43 I-53, 444. Canavan criticizes The Walking Dead's "uncriticial relationship" with its apparently "pre-feminist" view of women's role, which is "to code the ending as 'happy' or 'sad' based on their continued availability to bear the male protagonist's children." I suggest this sex-gender coding may be quite intentional and strategic in the show's elaboration of neoliberal agency and suffering. 
and his son Carl, following their increasingly grim and painful track through the show's post-apocalyptic, zombie-filled landscape. Although the swordwielding warrior Michonne (Danai Gurira) is a possible exception, most female characters in The Walking Dead's first three seasons adhere to this gendered division of narrative grammar in which identification and agency are investments in male characters, and female characters are there to expand, comment, or inform on the success or failure of the men. However, these men are placed in an increasingly untenable position, both because the world of the zombie apocalypse is a quintessential "no-win" situation and because Rick and Carl, and other newer male characters, are so often shown to be questionable, if not awful, people who make horrific, if not stupid, decisions. Given the stasis and despair of the plot and the often repellant nature of its main characters, the popularity of the show contravenes traditional dynamics of narrative identification.

What The Walking Dead does do, though, is offer a television template for the "suffering agency" described by Elliott in which neoliberal models of agency (distilled in mircroeconomic and choice theory into the elements of interest, choice, agential action) are taken to their logical conclusion, with the result that "the usually invisible suffering that accompanies the unfolding of this logic" is exposed and dramatized. ${ }^{19}$ The tensions undermining narrative identification demonstrate that although some sort of "nominal investment" in specific characters is key to the progression of the television and comic book narratives of The Walking Dead, something else is also going on, something that emerges from the very ambivalence of the audience's identification with the show's protagonists. Rick's character, for example, articulates a cyclical dynamic in which the male hero, whose leadership is seemingly designed to embody the audience's nostalgic and persistent investment in such a figure, is exposed as a serious problem, inevitably leading the group toward the destruction of all that he is supposed to "save."

Interestingly, a similar thwarting of identification and undermining of male heroism are important elements in the generic history of the Hollywood western, particularly during its more "critical" phase in the 1950s and I960s and exemplified in the films of John Ford, Sam Peckinpah, and John Sturges, among others. The long history of the "problem" of male heroism in classic westerns indicates that the narrative structure of The Walking Dead draws on more than just nostalgia when it references the genre of the western and the history of settler colonialism. Richard Slotkin's threevolume study of the western traces the specific economic and social shifts and crises that gave rise to the US myth of the frontier from its inception

19 Elliott, 94. 


\section{Katherine Sugg}

in the seventeenth century to the late twentieth century. ${ }^{20}$ And Canavan's penetrating essays on zombie narratives further argue that the genre's references to western tropes articulate a vivid critique of settler colonial histories of genocide and conquest, which are manifested in the brutality and violence of Rick Grimes and the others in their Hobbesian struggle for survival in the post-apocalypse.

I agree with Canavan that, among other things, the series signals the bankruptcy, and horror, of these colonial logics of race war, of a "war of all against all," or in Slotkin's terms a "savage war." In addition, though, I want to track what the two trajectories have to say to each other - what is articulated by the zombie temporality of reverting backwards into settler colonial history in order to articulate the futurity of liberal capitalism. The question for this essay becomes, to what extent was the racist and patriarchal logic of settler colonialism always already infected by the spectre of abjection and failure now being figured by the zombies of The Walking Dead and its narrative structure of impasse and wandering? And what does that slippage between logics and directions tell us about the internal dynamics and tensions within settler colonialism and the liberal capitalism it served?

\section{THE HORROR: LIBERALISM, AGENCY, AND ABJECTION IN THE WEST AND THE WALKING DEAD}

So Rick Grimes, who appears to be a figure for masculine (and thus liberal individualist) resistance to experiences of impotence and irrelevance within neoliberal systems of corporate and state control comes to embody a potential critique of liberal individual agency and masculine leadership. This agency and its notions of "leadership" are surreptitiously presented as a trap and an illusion for Rick and his followers. From the earliest episodes, Rick establishes his leadership by anticipating and preparing for violent attacks by the zombies and other human groups and responding fiercely with equal violence: as when he cuts off the leg of a young man impaled on a fence rather than leave him for the walkers to get. In some sense, his ruthless capacity for such acts serves as the clearest sign of Rick's natural leadership - even though we also see how that capacity is often in question, undermined by his desire to preserve community norms of justice, ethics, and sentimental attachment. For instance, although Rick did not want to abandon him to the zombies, the young man, Randall

${ }^{20}$ Richard Slotkin, Regeneration through Violence: The Mythology of the American Frontier, 1600-1890 (Middletown, CT: Wesleyan University Press, 1973); Slotkin, The Fatal Environment: The Myth of the Frontier in the Age of Industrialization, I800-I89o (New York: Antheneum, 1985); Slotkin, Gunfighter Nation: The Myth of the Frontier in Twentieth-Century America (New York: Antheneum, 1992). 
(Michael Zegen), had just attacked Rick and his friends. The rescued Randall, now lame, becomes a prisoner who is kept blindfolded and is later tortured for information and ultimately killed by Shane. As viewers and fellow survivors alike witness the futility of the group's actions and efforts to create a safe haven, the nature of Rick's leadership becomes more ambiguous underlining links between this very mode of leadership and the horrific consequences of the group's "savage war" against both the undead and other humans.

Binding the western's liberal individualist drama of white male leadership to the zombie apocalypse was never an accident. The show has morphed since its first two seasons into one that emphasizes (visually and plotwise) the line from settler colonial violence to contemporary political regimes of the prison, the detention center (and the Nazi concentration camp), and endless war. Its critical interrogation of "white male" leadership also recalls the dramas of masculinity that predominate Hollywood westerns and that genre's preoccupation with questions of both masculinity and governance. Patrick McGee suggests that the western's conservative reputation rests on two key pillars: its stress on "extreme versions of masculinity and individualism" and its status as "one of the principle narratives in the discourse of mass culture on the right to wealth and the legitimacy of class." ${ }^{21}$ But as McGee and others have noted, the social tensions and logical contradictions that uphold the western's mythical bundle of liberal individualism and masculine agency are often the very target of its later, more critical, generic elaborations.

Likewise, in its first seasons, The Walking Dead's own rhetorics of survival, savage war, and white male leadership pointedly re-create Western generic scenarios: saloon shoot-outs, armed confrontations on deserted roads, sheriffs, savages, and mercenary gunfighters. In the television show's second episode, Rick literally rides a horse, wearing his sheriff's uniform and a wide-brimmed cowboy hat, into a crowd of zombies, shooting his rifle indiscriminately (and futilely) at the hoard of rotting bodies enclosing him on the deserted city streets. Such iconic images of male heroism as a thing associated with "the West" are presented in a double-voiced narration that both emphasizes their echo of the "remembered" history of the West - including the figure of the lone, heroic sheriff - and yet also indicates an irony that undercuts those associations and their meaning. ${ }^{22}$ Rick's horse is quickly overcome by zombies and then eaten - on-screen and with emphatic sound effects

${ }^{21}$ Patrick McGee, From Shane to Kill Bill: Rethinking the Western (Malden, MA: Blackwell Publishing, 2007), xiv, xvii.

${ }^{22}$ See Mikhail Bakhtin, The Dialogic Imagination, ed. Michael Holquist, trans. Caryl Emerson and Michael Holquist (Austin: University of Texas, 198 I), 279, 284, on double-voiced narration as key narrative technique indicating a temporal or ideological shift, and also on the 
of gnawing, tearing, and chewing flesh - while Rick barely escapes. So even in its earliest episodes, The Walking Dead undermines the very capacities that its survivalist story would seem to promote: the main characters' actions sometimes do "save" the lives of their companions but just as often those actions are futile or even counterproductive. As in many key westerns, the violent acts and dubious motivations of the ostensible hero call into question the ethics and values of masculinity and leadership seemingly espoused and help uncover a history of imagining hegemonic white masculinity that is much more ambivalent and potentially "horrific" than is usually appreciated.

To this end, Richard Slotkin explicates the special function of the rhetoric of a "savage war" or "race war" in the economic enterprise of western expansion, an enterprise justified by depicting Native Americans as nonhuman others whose behaviors and interior subjectivities were understood as "simply the rage of a wild beast against the cage: visceral, unreasoning, an expression of a nature innately incapable of civilization." ${ }^{23}$ The inhuman other as horrific and thus as justifiably "killable" is reiterated in The Walking Dead's portrayal of Rick's commonsense approach to the zombies: he assumes a mandate to kill or be killed and expresses a total lack of concern for the former humanity of the now undead. However as Canavan notes, the series contrasts Rick's attitude to other characters' more humane (though often feminized as "weak") attitudes towards the zombies. This contrast makes visible and explicit the reliance on a logic of race war, an operation of expulsion and necessary violence, which Rick, and most of the others in his group, presume justifies their recourse to the rhetoric and methods of "savage war."

But there is also a generic and political history of understanding that these states of emergency are dangerous and ultimately unsustainable, in terms of both human psychic experience and community political norms. In particular, the rhetoric of "savage war" in the nineteenth century generated another discourse of the frontier as a "fatal environment" that produces "dangerous classes" (or a "peculiar race" of people known as frontiersmen). Slotkin details how the extreme acts of violence and the suspension of "civilized" norms of ethical and legal behaviors that were apparently required for survival in the frontier (and success in the western expansion) were in fact regarded with concern and alarm, as well as celebration and vindication, in the cosmopolitan centers of the nineteenth-century United States. This ambivalence expressed itself in cautionary tales detailing how the savagery of the frontier experience made "frontiersmen" - the first wave of adventurers and explorers

uses of irony in speech utterances that convey the coexistence of generic discourses in a parodic or dialogic relationship.

${ }_{23}$ Slotkin, The Fatal Environment, I 28. 
(and mercenaries and outlaws) who were responsible for the elimination of the Indians - unfit to function in civilized society. In many great westerns, including The Searchers and Shane, the ambivalence regarding the male hero culminates with his departure at the story's end, when he returns back into the wilderness from which he came. In these classic films, the iconic frontier antihero (also known as the gunfighter or "Indian-killer" figure) illustrates how the masculine subjectivities produced by classical liberalism have always been a problem.

As in the zombie apocalypse, the environment of the frontier, and the violence that is apparently necessary to survive there, combine in narratives that both assert the value of the protagonist's leadership, skills, and capacity for horrific acts and then question those acts - and the sort of person who commits them. In John Ford's The Searchers, the discourse of race war against Native Americans unravels in the character of Ethan Edwards (John Wayne) to expose the ambivalent trajectories of savagery and dangerous classes. On the one hand, the film shows Ethan to be a man who has the capacity to do what would cause others to shrink away in horror and impotence: such as in the famous scene in which Ethan alone confronts the unspeakable violence the Commanche have wrought on their women and insists, "Don't ever ask me. Long as you live, don't ever ask me more." These are scenes that establish Native Americans as enemies capable of inhuman barbarity, of acts that can neither be shown nor spoken. Though sometimes considered a racist apology for settler colonialism's genocidal war on Native Americans, McGee and others have argued that the real resolution offered in The Searchers occurs near the end of the film, when, in an act of vicious and gratuitous violence, Ethan scalps his enemy, the already dead Comanche chief Scar. By showing Ethan "becoming the savage," the film justifies Ethan's exclusion from the domestic and civil society that he has helped restore - showing how he is now one of the "dangerous classes," having sacrificed himself to the "fatal environment" of the frontier in order that others may come to live in relative peace and prosperity. ${ }^{24}$

This is the futurity of the frontier, where the simultaneous triumph and expulsion of the Indian-killer/frontiersman is a price paid by society in order to clear the way (literally) for that society's future. This foundational violence at the core of modern liberal democracy has been explored by political philosophers such as Giorgio Agamben and Achille Mbembe as a genealogy of power and capital that moves, necessarily, through colonial conquest, settlement, and slavery - and which is likewise foundational to the modes of government that administer the concentration camp, the occupied territories, the 
detention center, the prison, etc. While transposed to the fantasy of the zombie apocalypse, The Walking Dead emphasizes its links to those historical foundations by underlining of the generic concordance between the zombie apocalypse and the western. However, the television show also deploys another key genre of capitalism, horror, to introduce a specifically neoliberal twist on its fantasy of the frontier and futurity.

In his excellent chapter on zombie cinema, Evan Calder Williams describes the central affect of zombie horror films as one of "anxiety." But, echoing Berlant, Williams notes that "anxiety is never about the radically new but rather about the horrible possibility of the same persisting." ${ }^{25}$ Resonating with the critiques of Shaviro and Canavan, Williams insists that the double edge of the zombie narrative is located in the zombies themselves, who figure the condition (and threat) of labor in capitalism, particularly given the zombie myth's generic and genealogical origins in Haitian plantation slave society. For Williams, the "horror" of the best zombie films begins with their stripping of "everyday relations" to expose "the brutality beneath." But this horror is shadowed by impotent rage in Williams's view: "the seething anger at the prospect of not having a choice. The true underbelly of 'freely selling one's labor,' the realization that it has been a non-choice from the start." ${ }_{26}$ This characterization offers a pathway that connects the established critical understanding of zombies as "uncanny" and as figures of a compelling, even "ecstatic," abjection to the questions of agency and white masculinity that begin this essay.

The Walking Dead is known for its spectacularly grotesque special effects and the use of visual and aural technology to convey the disgust and horror, the "gore," that punctuate the experiences in this transformed landscape. The show consistently uses intense sound effects, as well as visuals, to make the bodily experiences of being bitten, chewed, and ripped apart inescapable and visceral for audiences. After the first three seasons, the horror of the zombie chronotope becomes familiar in ways that the show thematizes as a version of late capitalist horror. The premier episode of Season 4 opens with various characters doing their perimeter "patrol" along the chain-link fence that encloses the community (in a former prison), in which they use knives to loudly and grotesquely, but quite easily, "re-kill" the "roamers" that push and huddle against the enclosure. This management of the hoards of the undead is rendered in explicit camera close-ups and accompanied by sound effects that emphasize the experience of blade going through the skin, bone, soft organs, etc. of the zombie faces. After this initial scene, one of the newer

${ }^{25}$ Evan Calder Williams, Combined and Uneven Apocalypse (Winchester: Zero Books, 20 I I ), IOI.

26 Ibid., I I 5 . 


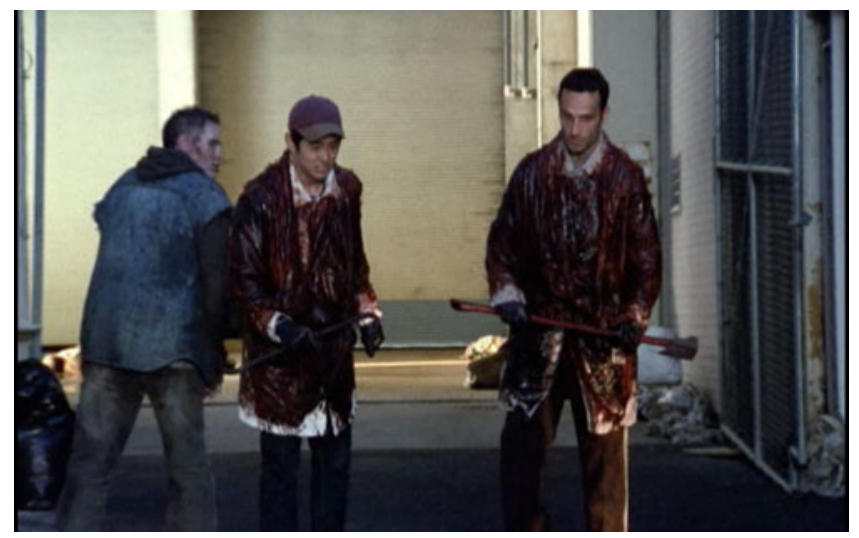

Figure 3. Rick Grimes (Andrew Lincoln) and Glenn (Steven Yeun) escape disguised as "walkers," Episode 2 ("Guts"), Season I, 20 Iо.

male characters asks to go out on a supply search in order to avoid this job of routine-maintenance violence (saying he "doesn't like it much"). His understatement ironically emphasizes that his character is "choosing" to risk his life in a direct and exposed situation rather than participate in the management of the walkers (and yes, he dies horrifically in the mission). Although Rick and the others maintain the rhetoric of "savage war" to justify and explain their violence, the actual "war" with the undead is shown here to be a relentlessly awful form of labor.

Problems of choice and hard decisions in The Walking Dead are presented so insistently as to feel almost ironic, but this insistence also makes clear how the show's preoccupation with "non-choice" is foregrounded from the start. The awful necessities imposed by the zombie apocalypse are dramatized as early as the second episode, when Rick and Glenn must escape from a building in downtown Atlanta that is being overrun by zombies. Glenn (Steven Yeun) is an Asian American former pizza delivery boy whose own, occasional, crises of masculinity in the first two seasons are presented as a counterpoint to Rick's capacities for action and self-sacrifice. From the opening shots, the viewpoint of the camera alternates between panoptic images of zombie hordes and closeups of the frantic efforts of Rick and Glenn to devise some sort of escape. In this scene, the porous line between living survivors and zombies is made material when Rick and Glenn smear themselves with zombie body gore, taken off bodies they've recently "killed," in order to camouflage their humanity by trying to smell and look like zombies (Figure 3). A generic set piece of zombie films, this "passing" in order to escape literalizes the ambivalence of survival and the precariousness of being "human," while foregrounding experiences of disgust and abjection. The requirement to overcome disgust in order to survive is shown here to involve overcoming the self's natural responses 
to the threat of defilement, rupturing self-defenses against any boundaryprotecting "line not to be crossed." The scene also signals the new extremes of doing what must be done: the self-inflicted horror involved in their camouflage will expand into the world they now inhabit, where characters must become more and more like the undead and the savage other, even if that transformation is in a sense against their will, compelled by the conditions of survival.

In The Walking Dead, even actions that appear autonomous or "chosen" are "forced" by the logics of survival and self-interest, to the extent that the horrific and otherwise indefensible act of cutting off your new girlfriend's arm and leaving her to die is a reasonable thing to do - and is what Rick does in the comic book series in order to save Carl from the approaching zombies. Rick's agency, like that of the Indian-killer Ethan Edwards, is thus constrained and locked within the field of relations, affective modes, and political imagination produced in the conditions of his experience, i.e. through his subjection as a neoliberal survivor (and a protagonist in a zombie-apocalypsegenre narrative). The role of white male hero is shown to be a trap within a logic that the protagonist cannot escape. Tortured and isolated by this logic, the "hero" is always in the process of "becoming a savage," of collapsing the distance between the self and the expelled, inhuman other. Psychoanalytic theory insists on the pivotal function of sexual difference in the logic of abjection: the ecstatic collapsing of boundaries between self and other is gendered exclusively as female, or feminine. ${ }^{27}$ In a sense, the loss of self threatened by abjection is precisely a loss of perceived agency, of capacity to act separately and autonomously.

Therefore a long genealogy of a specific mode of capitalist abjection is figured in the anguish and ambivalence of the white masculinity portrayed in The Walking Dead. Anna McCarthy asserts that "suffering is essentially an instructive public affect - it demarcates the limits of liberal and neoliberal rationality and exposes the forms of socioeconomic inequality and disenfranchisement that reside within the democratic experience." 28 Confronting, through fantasy, liberalism's impossible demands for agency, The Walking Dead could be said to impose a critical form of suffering on viewers who are propelled into the story by their "interest" in either the characters or the thought experiment of the apocalypse/survivalist situation and then find themselves entrapped, much as the characters are. Viewers' relation to the

${ }^{27}$ Julia Kristeva, Powers of Horror: An Essay on Abjection (New York: Columbia University Press, 1982), cautions that abjection is the source of jouissance (passion, pleasure, art, beauty, etc.) but is also "psychotic" and threatening to all subjective experience of oneself as a "bounded" subject.

${ }_{28}$ McCarthy, "Reality Television," 37-38. 
deterioration of the protagonists, and especially the "hero" and the seemingly "necessary" atrocities and horrors he commits, reflects the ambivalence installed in the character of Rick Grimes, and elaborated in the show's paradoxical temporality of "impasse."

Perhaps, though, is what looks like futility, an endless circling around the edges of previous towns and suburban enclaves, also an instructive form of suffering? In its distinct narrativity, one that is abject and vicarious but also forceful in the intensity of its anxiety, disgust, and boredom, The Walking Dead confronts the viewer with his, and her, "anxiety of the same" as well as a "seething anger" - the dual affective remainders of a growing proletarianization under neoliberal economic governance. Even further, The Walking Dead underlines the affective genealogies of liberal capitalism by revealing what happens in the afterward of the frontier, after the wandering and the genocides of The Searchers. Here, though, the survival narrative has fully turned on the characters, exposing a suffering that is self-perpetuating and zombified: a serial cycle that cannot be interrupted, survival without hope or choice. As Andrea says to Rick in Volume i9, "We don't die. You and me. That's the rule. We don't die" - and their undead state persists no matter what atrocities they commit, what horrors they experience. ${ }^{29}$ In this sense, The Walking Dead offers the frontier as the permanent landscape of late capitalism, and it will never end.

\section{AUTHOR BIOGRAPHY}

Katherine Sugg is Associate Professor of English and Coordinator of Latino Studies at Central Connecticut State University. Her publications include the book Gender and Allegory in Transamerican Fiction and Performance (2008). 